\section{ANALYSIS OF DESTINATION ATTRIBUTE AND QUALITY PERCEPTION OF ACEH HALAL TOURISM INTENTION: THE MEDIASION ROLE OF VISITOR SATISFACTION}

\author{
Fuadi $^{1}$, Reza Juanda ${ }^{2}$, Munardi ${ }^{3}$, Falahuddin ${ }^{4}$ \\ ${ }^{1,2,3,4}$ Universitas Malikussaleh \\ E-mail: ${ }^{1)}$ fuadi.msm@unimal.ac.id
}

\begin{abstract}
The COVID-19 pandemic is considered different from previous pandemics because of the extent and number of people infected. The impact of the COVID-19 pandemic has made almost all joints of the world economy sluggish, as a result it is estimated that the world economy will be in a recession. This also applies in Indonesia, where economic growth is not as expected. One of the sectors most impacted by this virus is the tourism industry and its derivatives, so it is very important to know and determine the right strategy in managing and seeing tourism opportunities in the midst of the pandemic and the aftermath as an effort to develop the world of sustainable tourism. The purpose of this study was to determine the impact of tourist satisfaction and perceived quality on the intention of halal tourism in the midst of a pandemic and in the future. Research on travel intentions in the midst of a pandemic, especially during the COVID-19 period, is still very limited, so that it will have an impact in the future, so further research needs to be carried out in a different context from the limitations of previous research. The research stages include; data observation, determining the main problem, the purpose of the activity, literature study, data collection, data processing, analysis of results, and evaluation of research results. This research is based on the theoretical framework of Destination Attributes and Perceived Quality. This study seeks to analyze the intentions of tourists traveling in the midst of the COVID-19 pandemic among the people of Aceh, Indonesia, and world tourists who travel to Banda Aceh City, Aceh Province. The data analysis method used a partial least squares (PLS) statistical approach with the structural equational model (SEM) method to see the direct and indirect effects (mediation). The findings of this study are expected to contribute to more effective planning for restoring the tourism business, specifically halal tourism and for the development of measures for destination attributes and visitor satisfaction and security in tourism services, now and in the future. The outputs in this study consist of research reports, articles in accredited national journals and produce HKI (copyright). The resulting TKT level of research is TKT 3.
\end{abstract}

Keywords: Destination Attribute, Quality Perception, Tourist Satisfaction, Halal Tourism Intention

\section{INTRODUCTION}

Tourism has become one of the national strategic sectors and has a double effect caused by tourism activities. The direct effect can be in the form of employment and indirect effects such as the development of restaurants, lodging, sellers of various souvenirs, souvenirs from tourist destinations as well as transportation and other services. Good and correct management of the tourism sector can increase economic growth by being grateful for creation. God Almighty by not destroying the existing environment. This is different from the oil and gas sector which continues to rely on the diminishing availability of fossil fuels.

The development of Islamic Economics has experienced a fairly rapid development and has become an important part of today's global economy. There are several sectors that have increased significantly, namely culinary, Islamic finance, insurance industry, fashion, cosmetics, 
pharmaceuticals, entertainment, and tourism. All of these sectors carry the halal concept in each of their products. There are several factors that have contributed to the rapid growth of the halal concept, namely the demographics of a large and relatively young Muslim market, fairly rapid economic growth, Islamic values that encourage the growth of an Islamic lifestyle, increased transactions between Muslim countries, participation of multinational companies, technology and connectivity. connectivity between countries (CrescentRating in Sofyan 2012). At a young gestational age (first trimester), women often experience nausea and vomiting (morning sickness). Nausea and vomiting occur due to changes in hormonal levels, namely increased levels of the hormone chorionic gonadortopin (HCG) from the placenta. If the nausea and vomiting become excessive (hyperemesis gravidarum), it will greatly affect the mother's weight so that additional nutrition in the form of vitamins and minerals is needed, while the need for calories and protein is very much needed in the eighth week until birth (Ariani, 2017).

There are several differences in various countries regarding the language of sharia tourism, including Halal Lifestyle, Muslim-Friendly Travel Destination, Halal Friendly Tourism Destination, Islamic Tourism and others. Sharia tourism products are considered as the latest breakthrough for tourism development in Indonesia which is very closely related to Islamic values. The public's view of sharia tourism is defined as a tour to the mosque. The concept of sharia tourism is The Concept of sharia tourism is not limited to religious tourism, but it extends to all forms of tourist except those that go against Islamic values. (Shakiry, 2006). The explanation explains the concept of sharia tourism is not limited to religious tourism but extends to various aspects in it that come from nature, culture, or artificial based on Islamic values.

In Indonesia, the naming of sharia tourism requires standardization by the government, this is due to the diversity of cultures and religions that exist in Indonesia. One of the polemics is the implementation of halal tourism in Aceh Province. Among these policies, there are those who support it with the aim of attracting Muslim tourists, but on the other hand, they think that this policy will eliminate the culture of local wisdom in the region. Even though the meaning of halal tourism is very broad and very open to all people. Aceh Province is one of the provinces prepared by the Indonesian government to become a sharia tourism destination with the potential for natural resources that attract domestic and international tourists. One of the cities is Banda Aceh City which is the capital city of Aceh Province, Indonesia. As the seat of government, Banda Aceh is the center of economic, political, social and cultural activities. The city of Banda Aceh is also the oldest Islamic city in Southeast Asia, where the city of Banda Aceh is the capital of the Aceh Sultanate.

The province of Aceh, especially the city of Banda Aceh, has a fairly thick culture and elements of the Islamic religion which are combined with quite good natural beauty, this is a good enough potential for local and foreign tourist destinations. With the enactment of halal tourism in the city of Sabang, it creates perceptions of non-Muslim tourists to visit. This condition is interesting if the condition is interesting if it is associated with the interest of Muslim tourists who choose halal tourism destinations in accordance with Islamic law.

\subsection{Formulation of the problem}

Based on the background and the problems that arise, the formulation of the problem to be answered in this study is:

1. What attributes in halal tourism affect perceptions of the quality offered by halal tourism in the city of Banda Aceh?

2. Perceptions of the quality offered by halal tourism destinations affect visitor satisfaction.

3. Visitor satisfaction influences future behavioral intentions

4. Perceptions of the quality offered by halal tourism affect behavioral intentions in the future.

\subsection{Research purposes}


The objectives of the research are:

1. What attributes in halal tourism affect perceptions of the quality offered by halal tourism in Banda Aceh City?

2. Perceptions of the quality offered by halal tourism destinations affect visitor satisfaction.

3. Visitor satisfaction influences future behavioral intentions

4. Perceptions of the quality offered by halal tourism affect behavioral intentions in the future.

\section{LITERATURE REVIEW}

\subsection{Destination Attribute}

In detail, Echtner and Brent Ritchie (2003: 45) mention four components of destination image measurement, namely:

1. Attributes-functional characteristic

Physical attributes associated with a city as a tourist destination. These attributes include: (a) the condition of the city's natural scenery, (b) the cost to meet the needs, (c) the climate, (d) the condition of tourist objects, (e) the conditions of night life and entertainment, (f) the conditions of various types of tourism. sports facilities, (g) the condition of city parks in the city, (h) the condition of infrastructure such as transportation, (i) the condition of various buildings, (j) the condition of ancient places, (k) the condition of the coast, (l) the condition of the center -shopping center, $(\mathrm{m})$ condition of various accommodations, (n) condition of the city, (o) condition of various major events, and (p) condition of various information regarding tourism.

2. Functional characteristic-holistic

Physical attributes that are functional and holistic relate to a city as a tourist destination. These attributes include: (a) residential density conditions, (b) cleanliness conditions, (c) comfort of living, (d) personal safety, (e) economic growth of Malang city, and (f) ease of various accesses in the city. 3. Holistic - psychological characteristic

Physical attributes that are holistic and psychological relate to a city as a tourist destination. These attributes include: (a) urbanization regularity, (b) urban business development, (c) urban political stability, (d) population friendliness, and (e) cultural differences.

4. Attributes - Psychological characteristic

Psychological physical attributes associated with a city as a tourist destination. These attributes include: (a) culinary differences (many unique foods from other cities), (b) comfort of resting places (inns), (c) beautiful environment, (d) opportunities for adventure, (e) opportunities to develop knowledge, (f) a sense of community kinship, (g) service quality (drinking water, lighting, telephone, etc.), and (h) reputation.

\subsection{Quality Perception}

According to Aliman et al, (2016: 213) Perception of service quality is determined by customer perception. Perception of quality is the perception of customers when providing services such as the expected service. If the expected quality is the same as the previous quality experience, it will create a perception of the quality of the neutral state obtained (Verma, 2012: 411-566). Indicators of perceived quality: 1) Perception of the quality of tour guides, 2) Perception of environmental quality, 3) Perception of accommodation quality, 4) Perception of quality of transportation, 5) Perception of the quality of tourist objects.

\subsection{Halal Tourism Intention}

The theory of consumer intention is based on the theory of reason to act (Ajzen \& Fishbein 1975). This theory assumes that consumers always consider consciously the consequences of choosing an alternative that results in the desire (intention) to do/act in accordance with the behavioral choices. A person's intention to buy a product/service is influenced by a person's attitude towards purchasing behavior and subjective norms, Munandar (2014). Meanwhile, according to Dharmmesta (1998) intentions are related to attitudes and behavior. Intention is considered as a 
catcher or intermediary between motivational factors that influence behavior. Intention shows how much effort a person plans to do something and intention is related to subsequent behavior. A consumer's buying behavior occurs for a certain reason, especially for consumers who are in a condition: (a)have the freedom of choice in their purchases and (b) not being dominated by the emotional aspect when carrying out the decision-making process.

\section{RESEARCH METHODS}

\subsection{Research Objects and Locations}

This research was conducted in Banda Aceh City, Aceh Province, Republic of Indonesia. Meanwhile, the object of this research is Destination Attributes and Perceived Quality in Halal Tourism Intentions in Banda Aceh City.

\subsection{Population and Sample}

The population in this study is the Muslim community as local tourists and national tourists, who visit Banda Aceh City, Aceh Province for sightseeing trips. Meanwhile, the sampling technique used is Non Probability Sampling with an accidental sampling approach. The number of samples studied amounted to 100 respondents.

\subsection{Data Collection Method}

To obtain primary data related to the results of this study, the data collection method that the author did was to use a structured questionnaire. Secondary data is supporting data, which the author obtained by studying the literature containing information related to the problem being researched and books and articles related to the research theme.

\subsection{Data analysis method}

The data analysis approach used is descriptive and verification analysis. Descriptive analysis is an analysis of primary data using statistical means, percentages, and graphs. The purpose of this analysis is to clearly describe the independent variables studied in this study. Meanwhile, the verification analysis is the use of a partial least square (PLS) statistical tool with the structural equational model (SEM) method to see the direct and indirect effects (mediation).

\section{RESEARCH RESULTS AND DISCUSSION}

\subsection{Instrument Test \\ 4.1.1 Validity Test}

Table 1. Validity Test Results

\begin{tabular}{|c|c|c|c|}
\hline \multicolumn{4}{|c|}{ NIAT BERWISATA (Y) } \\
\hline Pernyataan & $\mathbf{r}_{\text {hitung }}$ & $r_{\text {tabel }}$ & Validitas \\
\hline 1 & 0,469 & 0,163 & Valid \\
\hline 2 & 0,182 & 0,163 & Valid \\
\hline 3 & 0,910 & 0,163 & Valid \\
\hline 4 & 0,150 & 0,163 & Valid \\
\hline \multicolumn{4}{|c|}{ ATRIBUT DESTINASI WISATA HALAL (X1) } \\
\hline Pernyataan & $\mathbf{r}_{\text {hitung }}$ & $\mathrm{r}_{\text {tabel }}$ & Validitas \\
\hline 1 & 0,979 & 0,163 & Valid \\
\hline 2 & 0,973 & 0,163 & Valid \\
\hline 3 & 0,599 & 0,163 & Valid \\
\hline 4 & 0,538 & 0,163 & Valid \\
\hline \multicolumn{4}{|c|}{ PERSEPSI (X2) } \\
\hline 1 & 0,892 & 0,163 & Valid \\
\hline 2 & 0,290 & 0,163 & Valid \\
\hline 3 & 0,789 & 0,163 & Valid \\
\hline 4 & 0,500 & 0,163 & Valid \\
\hline \multicolumn{4}{|c|}{ KEPUASAN (Z) } \\
\hline 1 & 0,761 & 0,163 & Valid \\
\hline 2 & 0681 & 0,163 & Valid \\
\hline 3 & 0,603 & 0,163 & Valid \\
\hline 4 & 0,655 & 0,163 & Valid \\
\hline
\end{tabular}

Source: Processed data (2021)

Table 1 shows that all statement points, both the Travel Intention variable (Y), Halal Tourism Destination Attributes (X1), Transactional Leadership (X2), Satisfaction (X3), have a 


\section{ORFAI JOURNAL \\ Multidiciplinary Output Research For \\ Actual and International Issue}

higher $r$ value than the $r$ table value, so it can be concluded if all statements of each variable are declared valid.

\subsubsection{Reliability Test}

Table 2. Reliability Test Results

\begin{tabular}{|lccc|}
\hline \multicolumn{1}{|c}{ Variabel } & $\begin{array}{c}\text { Cronbach } \\
\text { Alpha }\end{array}$ & Konstanta & Reliabilitas \\
\hline Atribut Destinasi Wisata Halal (X1) & 0,811 & 0,6 & Reliabel \\
Persepsi (X2) & 0,742 & 0,6 & Reliabel \\
Niat Berwisata (Y) & 0,791 & 0,6 & Reliabel \\
Kepuasan (Z) & 0,742 & 0,6 & Reliabel \\
\hline
\end{tabular}

Source: Processed data (2021)

Based on the reliability test using Cronbach Alpha, all research variables are reliable because Cronbach Alpha is greater than 0.6, so the results of this study indicate that the measurement tool in this study has met the reliability test (reliable and can be used as a measuring instrument).

\subsubsection{Measurement Model Test Results (Outer Model)}

The measurement model is a model with calculation results based on calculations using the PLS program.

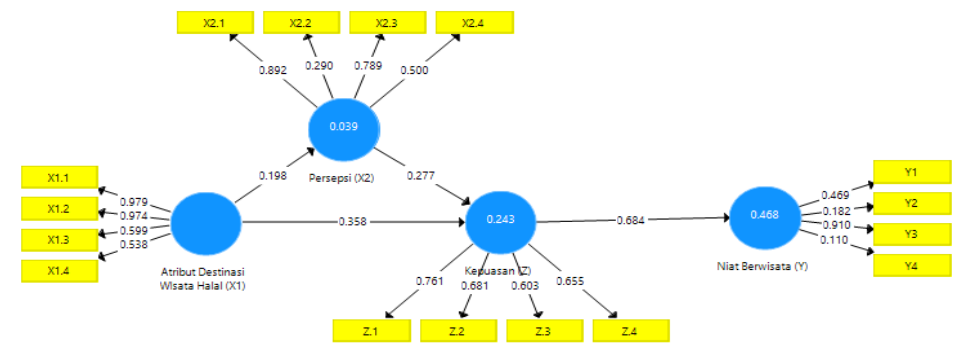

Figure 1.PLS Algorithm Calculation Results Display

\subsubsection{Structural Model Testing Results (Inner Model)}

After the model is estimated and meets the criteria for convergent validity, discriminant validity and reliability, the structural model testing phase (inner model) is then carried out. This stage is carried out after obtaining the ideal model in accordance with the conceptual framework of the study.

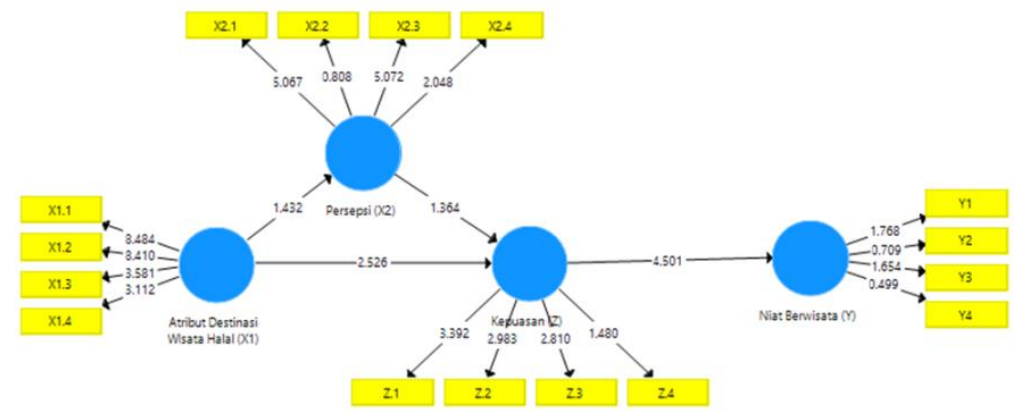

Figure 2.PLS Boothstrapping Results Display

To assess the significance of the prediction model in structural model testing, it can be seen from the t-statistic value between the independent variables to the dependent variable in the Path Coefficient table at the SmartPLS output below: 
Analysis Of Destination Attribute And Quality Perception Of Aceh Halal Tourism Intention: The Mediasion Role Of Visitor Satisfaction

DOI: $10.54443 /$ morfai.v1i2.98

Table 3. Path Coefficients (Mean, STDEV, t-Value)

\begin{tabular}{|l|c|c|c|c|c|}
\hline & $\begin{array}{c}\text { Original } \\
\text { Sample }\end{array}$ & $\begin{array}{c}\text { Sample } \\
\text { Mean }\end{array}$ & $\begin{array}{c}\text { Standar } \\
\text { Deviasi }\end{array}$ & T Statistic & P Value \\
\hline $\begin{array}{l}\text { Atribut Destinasi Wisata } \\
\text { Halal (X1) - Kepuasan } \\
\text { (Z) }\end{array}$ & 0,358 & 0,335 & 0,142 & 2,526 & 0,012 \\
\hline $\begin{array}{l}\text { Atribut Destinasi Wisata } \\
\text { Halal (X1) - Persepsi } \\
(\mathrm{X} 2)\end{array}$ & 0,198 & 0,242 & 0,138 & 1,432 & 0,158 \\
\hline $\begin{array}{l}\text { Kepuasan (Z) - Niat } \\
\text { Berwisata (Y) }\end{array}$ & 0,684 & 0,686 & 0,152 & 4,501 & 0,000 \\
\hline $\begin{array}{l}\text { Persepsi (X2) - } \\
\text { Kepuasan (Z) }\end{array}$ & 0.277 & 0.279 & 0.203 & 1,364 & 0,173 \\
\hline
\end{tabular}

\section{Correlation Test Analysis}

Table 4. Variance Inflation Factor Correlation Test

\begin{tabular}{|l|l|r|}
\hline & Kepuasan (Z) & Niat Berwisata (Y) \\
\hline Atribut Destinasi Wisata Halal (X1) & 1,178 & 1,411 \\
\hline Persepsi (X2) & 1,178 & 2,301 \\
\hline Kepuasan (Z) & & \\
\hline Niat Berwisata (Y) & & 1,359 \\
\hline Efek Moderasi X1*X2 & & \\
\hline
\end{tabular}

Source: PLS Output Results

Based on the results of the VIF correlation table output, it can be seen that the Variance Inflation Factor/VIF value of all research variables is $<5.00$, so it can be concluded that there are no symptoms of multicollinearity in this research model.

\section{Path Coefficient Analysis}

Table 5.Path Coefficients Value before Intervening Effect

\begin{tabular}{|l|r|l|}
\hline & Kepuasan $(\mathrm{Z})$ & Niat Berwisata $(\mathbf{Y})$ \\
\hline Atribut Destinasi Wisata Halal (X1) & 0,247 & \\
\hline Persepsi (X2) & 0,290 & \\
\hline
\end{tabular}

Source: PLS Output Results

Based on table 5 above, the structural equations formed in this study are as follows:

Travel Intention $=0.196$ Halal Tourism Destination Attribute $+\mathbf{0 . 6 7 3}$ Perception

Economic growth $=0.196$ Halal Tourism Destination Attributes +0.673 Perception.

The Attribute Variable of Halal Tourism Destinations, Perception, has a positive coefficient value. This shows that if the variables above are increasing, the intention to travel will also increase.

The results of data processing with the PLS Algorithm Smart PLS program in assessing path coefficients with intervening effects can be seen in Table 6 below.

Table 6 Path Coefficients Value with Intervening Effect

\begin{tabular}{|l|r|}
\hline & \multicolumn{2}{|c|}{ Pertumbuhan Ekonomi (Y) } \\
\hline Atribut Destinasi Wisata Halal (X1) & 0,326 \\
\hline Persepsi (X2) & 0,247 \\
\hline Efek Moderasi X1*X2 & $-0,099$ \\
\hline
\end{tabular}

Source: PLS Output Results

Based on Table 6 above, the structural equations formed in this study are as follows:

$\mathrm{NB}=0.387 \mathrm{ADWH}+0.254 \mathrm{P}-0.099\left(\mathrm{KTF}^{*} \mathrm{KS}\right)-0.009(\mathrm{ADWH} * \mathrm{P})$

Travel Intention $=0.326$ Halal Tourism Destination Attribute +0.247 Perception +0.240 Perception - 0.099 Halal Tourism Destination Attribute * Perception. 


\section{OMRFAI JOURNAL Actual and International Issue}

Variable Attributes of Halal Tourism Destinations (X1), Perception (X2), have a positive coefficient value. It is assumed that if there is an increase in the independent variable, the dependent variable will increase. So it can be concluded that if the above variables are increasing, it will also increase Travel Intention.

The results of the moderating interaction between the Attributes of Halal Tourism Destinations and Perception has a negative coefficient value. It is assumed that if Competitive Advantage has an impact on Travel Intentions, its influence will be stronger when playing a visitor role because of the habit of visitors traveling to entertain themselves or their families and not on vacation when they are working, sharing information and knowledge, so that they can provide knowledge of halal tourism.

\subsection{Descriptive statistics}

Table 7. Descriptive statistics

\begin{tabular}{|l|c|c|c|c|}
\hline & Niat_Berwisata_Y & $\begin{array}{c}\text { Atribut_Destinasi } \\
\text { _Wisata_Halal } \\
\text { _X1 }\end{array}$ & Persepsi_X2 & Kepuasan_Z \\
\hline Mean & 1.459200 & 44.03537 & 1.574600 & 1.330886 \\
\hline Median & 1.334000 & 1.345000 & 1.344000 & 1.556000 \\
\hline Maximum & 2.397000 & 1492.000 & 3.127000 & 2.833000 \\
\hline Minimum & 0.140000 & 0.116000 & 0.189000 & 0.152000 \\
\hline Std. Dev. & 0.503188 & 249.0384 & 0.694675 & 0.779232 \\
\hline & & & & 100 \\
\hline Observations & 100 & 100 & 100 & \\
\hline
\end{tabular}

Source: PLS Output Results

Based on table 4.5 above, it can be seen that the number of observations made for travel intentions in this study were 100 observations. The lowest value of travel intention in this study is 0.140000 and the highest value is 2.397000 . The average value of the travel intention variable is 1.459200 with a standard deviation of 0.503188 . The standard deviation value is smaller than the average value. This shows that the intention to travel is low in the sample in this study.

Furthermore, the observations made for the attributes of halal tourist destinations in this study were 100 observations. The lowest value of the attribute of halal tourism destinations in this study is 0.116000 and the highest value is 1492,000 . The average value of the attribute variable for halal tourism destinations is 44.03537 with a standard deviation of 249.0384 . The standard deviation value is greater than the average value. This shows that the attribute variables of halal tourism destinations are high in the sample in this study.

The observations made for perception in this study were 100 observations. The lowest value of perception in this study is 0.189000 and the highest value is 3.127000 . The average value of perception is 1.574600 with a standard deviation of 0.694675 . The standard deviation value is lower than the mean value. This shows that the low level of perception in the sample will affect this research.

The observations made for satisfaction in this study were 100 observations. The lowest value of satisfaction in this study is 0.152000 and the highest value is 2.833000 . The average value of satisfaction is 1.330886 with a standard deviation of 0.779232 . The standard deviation value is lower than the mean value. This indicates a low level of satisfaction in the sample of this study.

\section{Hypothesis test}

Table 8. Path Analysis Test (Intervening) 
Volumes 1 No 2 (2021)

Analysis Of Destination Attribute And Quality Perception Of Aceh Halal Tourism Intention: The Mediasion Role Of Visitor Satisfaction

DOI: $10.54443 /$ morfai.v1i2.98

\begin{tabular}{|l|l|l|l|l|l|}
\hline & $\begin{array}{l}\text { Path } \\
\text { Coefficients }\end{array}$ & $\begin{array}{r}\text { Sample } \\
\text { Mea } \\
\text { n }\end{array}$ & $\begin{array}{l}\text { Standar } \\
\text { Deviasi }\end{array}$ & T Statistic & P Value \\
\hline $\begin{array}{c}\text { Atribut Destinasi Wisata } \\
\text { Halal (X1) -0,055 } \\
\text { Kepuasan (Z) }\end{array}$ & 0,056 & 0,062 & 0,876 & 0,381 \\
\hline $\begin{array}{c}\text { Atribut Destinasi Wisata } \\
\text { Halal (X1) Niat0,282 } \\
\text { Berwisata (Y) }\end{array}$ & 0,254 & 0,092 & 3,069 & 0,002 \\
\hline $\begin{array}{c}\text { Atribut Destinasi Wisata } \\
\text { Halal (X1)- Persepsi } \\
\text { (X2) }\end{array}$ & & & & \\
\hline $\begin{array}{c}\text { Kepuasan (Z) - Niat } \\
\text { Berwisata (Y) }\end{array}$ & & & & \\
\hline $\begin{array}{c}\text { Persepsi (X2) - Kepuasan } \\
\text { (Z) }\end{array}$ & & & & \\
\hline $\begin{array}{c}\text { Persepsi (X2) - Niat } 0.189 \\
\text { Berwisata (Y) }\end{array}$ & 0.171 & 0.140 & 1,351 & 0,177 \\
\hline
\end{tabular}

Source: PLS Output Results

Based on the test results in table 4.8 above, the test results for each hypothesis are as follows:

1. The test results shown in table 4.8 show the Path Coefficients value of Halal Tourism Destination Attributes (X1) -> Satisfaction (Z) of 0.381 not significant at t-statistic 0.876 smaller than t-table 1.97 and at P-value 0.381 smaller of a significance level of 0.05 . Thus the hypothesis which states that the Attributes of Halal Tourism Destinations has no significant effect on Satisfaction can be rejected (H1 is rejected), or in other words, there is no significant effect of the Attributes of Halal Tourism Destinations on visitor satisfaction.

2. The test results shown in table 4.8 show the path coefficient value Attributes of Halal Tourist Destinations $(\mathrm{X} 1)->$ Travel Intention $(\mathrm{Y})$ of 0.282 is not significant at the t-statistic 3.069 which is greater than the t-table of 1.97 and the P-value of 0.002 is smaller than the 0.05 level of significance. Thus the hypothesis which states that there is a significant effect of Halal Tourism Destination Attributes on Travel Intentions is acceptable (H2 is accepted), or in other words there is a significant influence of Halal Tourism Destination Attributes on Travel Intentions.

3. The test results shown in table 4.8 show the path coefficient value of the direct influence of Perception (X2) -> Travel Intention (Y) of -0.189 at a t-statistic of 1.351 greater than t-table 1.97 and at a P-value of 0.177 greater than significance level of 0.05 . Thus the hypothesis which states that there is no significant effect of perception on travel intentions can be rejected (H2 is rejected), or in other words there is no significant effect of perception on travel intentions.

\section{CONCLUSION}

Based on the results of the data analysis that has been carried out, several conclusions can be drawn in this study, namely as follows:

1. The test results of the path coefficient value show that the Attributes of Halal Tourism Destinations have no significant effect on Satisfaction can be rejected (H1 is rejected), or in other words there is no significant effect of the Attributes of Halal Tourism Destinations on visitor satisfaction.

2. The test results of the path coefficient value show that there is a significant effect Attributes of Halal Tourism Destinations on Travel Intentions are acceptable (H2 is accepted), or in other words there is a significant influence of Halal Tourism Destinations' Attributes on Travel Intentions.

3. The test results of the path coefficient value show that there is no significant effect Perception of Travel Intention can be rejected ( $\mathrm{H} 2$ is rejected), or in other words, there is no significant influence of perception on Travel Intention. 


\section{REFERENCES}

Aliman, NK, Hashim, Shareena, MH, Siti, DMW \& Syahmi, H. (2016). "Tourists' Satisfaction with a Destination: An Investigation on Visitors to Langkawi Island". International Journal of Marketing Studies; 8(3).

Battour, M., Ismail, NM, Battor, M., \& Awais, M. (2017). Islamic Tourism: An Empirical Examination of Travel Motivation and Satisfaction in Malaysia. Current Issues in Tourism, 20, 50-51. doi.org/10.1080/13683500.2014.965665.

Bucak, Turgay. (2014). The Effect Of Service Quality On Customer Satisfaction: A. Research On Customer Satisfaction: A Research On Hotel Businesses.

David Bowen,Alexander F. Schouten (2018), Tourist satisfaction and beyond: tourist migrants in Mallorca, International Journal of Tourism Research. https://doi.org/10.1002/jtr.647.

Dharmmesta, Basu Swastha (1998) Theory Of Planned Behavior In Research Attitudes, Intentions, \& Consumer Behavior. MANAGE Volume 18 Number 7.

Echtner CM and B Ritchie, (2003), The Meaning and Measurement of Destination Image. The Journal of Tourism Studies Vol. 14. No. 1.

Fajar Peunoh Daly, 140602168 (2018) The Effect of Halal Tourism on Tourist Satisfaction Visiting Banda Aceh City. Thesis thesis, UIN Ar-Raniry Banda Aceh.https://repository.ar-raniry.ac.id/id/eprint/9926/.

Fishbein, M., \& Ajzen, I (1975). Belief, Intention, And Behavior: An Introduction to Theory and Research. Reading, MA: Addison-Wesley.

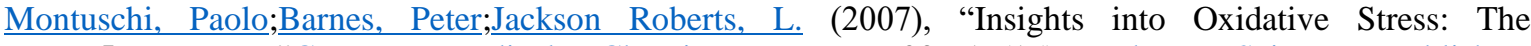
Isoprostanes"Current Medical Chemistry. pp. 703-717(15).Bentham Science Publishers DOI:doi.org/10.2174/09298677780059607.

Munandar. (2014) "The Influence of Attitudes and Subjective Norms on Intentions to Use Sharia Banking Products at Aceh Sharia Banks in Lhokseumawe City" VISIONER \& STRATEGIC JOURNAL Volume 3, Number 2, September $2014 \quad$ ISSN : 2338-2864 p. 7380.http://repository.unimal.ac.id/id/eprint/206.

Pujiastuti, Eny Endah; Sadeli, Sadeli; Destiana, Anisa. (2021), The Effect of Destination Image and Tourist Attraction on Tourist Satisfaction and Post Visit Behavioral Intention. Journal of Tourism and Creativity.https://doi.org/10.19184/jtc.v3i2.14014.

Ramjit(2013). "Customer Experience and its Relative Influence on Satisfaction and Behavioral Intention in Hospitality and Tourism Industry”. PS Manhas.

Suwena, Widyatmaja. (2017). Basic Knowledge of Tourism Science. Library Publisher. Laras, Bali.

Wiwik Suprihati(2020)"Analysis of Tourist Consumer Behavior in the Era of the Covid-19 Pandemic (Case Study of Tourism in West Nusa Tenggara)” Bestari Journal. Volume 01 Number.01, P.56-66.

W. Jeffrey Elias, MD, Nir Lipsman, MD, Ph.D., Et Al. (2016), A Randomized Trial Of Focused Ultrasound Thalamotomy For Essential Tremor. Doi: 10.1056/Nejmoa1600159.

Notes:

Thank's A Lot To Radja Publica As The Head Officer Of Ijebas Journal Who Has Facilitated The Process Of Publishing This Scientific Article And Also Especially To Lppm Malikussaleh University. Who Is Willing To Cooperate In The Process Of Publishing Articles About Analysis of Destination Attributes and Quality Perceptions of Aceh Halal Tourism Intentions: The Mediation Role Of Visitor Satisfaction 
Volumes 1 No 2 (2021)

Analysis Of Destination Attribute And Quality Perception Of Aceh Halal Tourism Intention: The Mediasion Role Of Visitor Satisfaction

DOI: $10.54443 /$ morfai.v1i2.98 